\title{
Governance and Efficiency of Zakah Distributions Based on the Dire Necessities of Maqasid Al-Syariah
}

\author{
Maheran Zakaria ${ }^{1}$, Muhammad Saiful Anuar Yusoff ${ }^{2} \&$ Zuraidah Sanusi $^{1}$ \\ ${ }^{1}$ Accounting Research Institute, Universiti Teknologi MARA, Malaysia \\ ${ }^{2}$ Universiti Teknologi MARA Kelantan, Malaysia \\ Correspondence: Maheran Zakaria, Accounting Research Institute, Universiti Teknologi MARA, Malaysia.
}

Received: April 30, 2019

Accepted: May 30, 2019

Online Published: June 10, 2019

doi:10.5430/ijfr.v10n5p191

URL: https://doi.org/10.5430/ijfr.v10n5p191

\begin{abstract}
The study examines the governance and efficiency of zakah distributions based on the fulfilment of five dire necessities (daruriyyat) of Maqasid al-Syariah. There were about 500 questionnaires distributed to zakah beneficiarys of Asnaf Business Assistance program governed by one of Malaysian State Religious Council. 456 respondents responded, contributing to 89 per cent rate of response. Structural Equation Modelling with the use of Partial Least Square was used to analyse the data. Based on the findings, it can be concluded that the more likely the five elements of dire necessities namely faith, physical self, knowledge, family, and wealth being fulfilled, the more likely is the efficiency of zakah distributions. The study provides useful insights to zakah institutions to formulate strategies in relation to 5 elements of dire necessities to ensure competent distribution of the fund to recipients. The results would also provide comprehensive insights to other empirical studies in this area which will not only be applicable to Muslim countries but to non-muslim countries as well.
\end{abstract}

Keywords: dire necessities (daruriyyat), efficiency, Maqasid al-Syariah, Zakah institutions

\section{Introduction}

Islam is dedicated to establishing a sound economic system that emphasises on social welfare, economic justice and the equitable distribution of income within the community. Zakah is one of the mechanisms ordained by the creator, Allah S.W.T. to materialise this objective by eliminating inequalities through the redistribution of wealth income from the wealthy to the unfortunate groups.

Zakah is the third pillar of faith in Islam and is also referred to as alms giving that symbolises purification, growth and blessing. The order of giving zakah is repeatedly stressed in the Noble Quran in conjunction with salah (prayer) as both deeds denote purification. Purification exists in two forms; the first is purification of the heart from the detested trait of stinginess, greed and love of possession and the second is purification of wealth by giving out a portion of wealth and through God's blessing, the wealth will grow.

In one verse in the Noble Quran, Allah (SWT) commands to His Messenger (SAW) which is interpreted as "Of their wealth take alms so that, through it, you may purify and sanctify them..." [Surah At-Tawbah (9:103)]. A Muslim who owns an excess of wealth and income is obligated to share a portion of his means with the asnaf, those entitled to receive. The asnaf consists of eight (8) groups, namely poor (masakin), destitute (faqir), zakat collector (amil), needy traveller (inn-sabil), Muslim convert (muallaf), heavily indebted creditor (al-gharimin), people who strive in the path of Allah ( $f$ i sabilillah) and slaves who want to free themselves from the master.

In Malaysia, zakah is governed by zakah institution of which it is under the auspices of the respective State Religious Council. Malaysia has 14 states and each state has its own zakah institution, totalling to 14 institutions. Each zakah institution adopts its individual approach with the same primary objective to distribute wealth from zakah payer to the asnaf. In this context, practising good governance and maximising efficiency in zakah institutions are essential in ensuring that the distribution of zakah fulfils the dire necessities of the beneficiaries (asnaf).

Furthermore, as a public organisation, zakah institution is entrusted to administer the collection and distribution of zakah for the development of the Muslim community. According to Wahid and Kader (2010), the efficiency of zakah collection and distribution mainly depend on the good governance of zakat institutions and it is also found that an institution that exercises good governance would manage its affairs efficiently (Abd Wahab and Abdul Rahman, 
2012; Lari, NYangweso \& Rono 2017). The interrelation of governance and efficiency is reflected in the ability of zakah institution to transform the beneficiaries' living status from being able to meet daruriyyat needs to the level of comfort or hajiyyat (Abu Bakar and Ghani, 2011; Abdul Rasool et al., 2010; Khan,et.al 2016; Zakaria, 2018). Due to this major transformation, the poor can then independently support themselves and their family as they are no longer considered as eligible zakah beneficiaries or asnaf.

According to Maqasid al-Syariah, there are three categories of needs in human's life. The lowest basic category is dire necessities (daruriyyat), where one strives to fulfil these needs before desiring other needs. Dire necessities refer to a desperate situation in which one requires immediate financial and non-financial assistance to support his or her well-being. Dire necessities include faith, food, home, clothing, education and family etc. Deprivation of these needs renders one's life no positive quality. Comfort needs (hajiyyat) is in the second category outlined in Maqasid al-Syariah. Once the fulfilment of daruriyyat needs is achieved, one would be motivated to fulfil hajiyyat needs such as living in a comfortable house and eating nutritious food. The highest category of needs is tahsiniyyat (luxury) needs where one is driven to fulfil these needs as the symbol of wealth and luxury. It is significant to note that while basic needs and comfort living (hajiyyat) are the supreme of all needs, tahsiniyyat needs are of less priority but still encouraged (Abu Bakar and Abd Ghani, 2011; Khan \& Ali 2017; Lan, Lin \& Lin 2017).

Zakat is one of the economic mechanisms in Islam as ordained by Allah S.W.T to eradicate poverty in society. Although statistics have indicated that the collection of zakah in the states is increasing, poverty in the country still persists, especially within the Muslim community (Malaysian Statistic Department, 2016). This contradicts with the economic stability that happened under the reign of Caliph Umar Ab. Aziz (al Zuhaily, 2005). During his ruling, the beauty of zakah prevailed as the fund had successfully transformed the lives of the poor to comfortable living. This led to a surplus in the zakah fund as there were no eligible beneficiaries and eventually, the funds were channelled for the development activities for the society.

The situation in Malaysia inflicts doubtful perceptions towards the efficiency of zakah institutions in distributing zakah fund. Consequently, this could undermine the public's confidence in the institutions' ability to exercise good governance. As an entrusted agent, zakah institution is always under public scrutiny and criticisms. Many hope that zakah fund will totally alleviate poverty and this can only be realised through good governance and efficiency of zakah institutions in executing their duties competently.

To date, many empirical studies have examined the dire necessities of Maqasid al-Syariah with regards to the efficiency of zakah distribution (Zakaria 2014; Zakaria and Abd Malek, 2014; Rosbi and Sanep 2009; Kojo \& Paschal 2018). Despite the empirical outcomes, these studies considered all five dimensions of dire necessities as one variable in relation to zakah distribution efficiency. The five (5) basic needs as described in Maqasid al-Syariah were not examined independently or as a separate variable and analysed in relation to governance and efficiency of zakah distribution.

It is crucial to investigate the issue of individual dimension of dire necessities to ensure that proper assistance can be deployed to tackle the deprivation of these necessities. Therefore, with the awareness of inadequacies present in existing researches, the objective of this study is to examine the influence of every single dimension of the five dire necessities (daruriyyat) of Maqasid al-Syariah, namely preservation of faith, knowledge, self, offspring and wealth on the governance and efficiency of zakah distributions.

With regards to the organisation of this paper, the next section highlights on the governance and efficiency of zakah distributions a review on humans' dire necessities is presented in section 3. This is then followed by results and analyses in section 4 . Section 5 discusses the implications and limitations for future studies. Finally, this paper ends with a conclusion in section 6 .

\section{Literature Review}

\subsection{Governance and Efficiency of Zakah Distribution}

Governance refers to the process and structure in directing and managing the affairs of an institution. Efficiency, on the other hand, is a term used to measure how well an institution utilises its resources including human resources, expenses, funds and assets to meet its objective (Farrell, 1957). Hence, all institutions are expected to exercise good governance and manage their affairs efficiently towards achieving the institutional objectives.

Kaplan and Norton (1996) introduced a performance tool called Balanced Score Card to measure governance and efficiency of a programme. This measurement includes non-financial and financial assessments. These assessments provide a more balanced view of organisational performance in relation to four dimensions, namely customer satisfaction, internal processes, knowledge worker and financial performance. 
In terms of the first dimension i.e., customer satisfaction, prior to offering the required product or programme to customers, the institution should identify its potential customers in the targeted market first. The second dimension is the knowledge worker that stresses on innovation, creativity, competency and capability of the institution's human resources. The objective of this dimension is to assess the efficiency of the institution's human resources in managing and governing the programme (Cohen et al., 2008; Khan, et.al 2018). Additionally, attitude, knowledge, development, skills and the ability of the workers to learn and improve are also considered. The third dimension is internal process which measures the procedures adopted by the institution in running the programme based on critical process, skills, competencies and technologies (Atkinson, 2000). Financial performance is the last dimension which indicates the ability of the institution to complete and achieve the objective of the programme.

As an entrusted socio-economic agency, the ultimate objective of zakah institution is to conduct social religious obligation while adhering to the requirement of syariah. The institution is expected to exercise good governance and manage the distribution of zakah fund efficiently. This is to ensure that the institution's accountability to zakah payers is maintained.

As elaborated above, previous studies have examined the efficiency of zakah distribution by analysing Balanced Score Card's indicators in relation to human needs of Maqasid al-Syariah (Zakaria and Abd Malek, 2014; Zakaria, 2014; Lee, Ismail \& Sanusi 2018). Following prior studies, the current paper measures the governance and efficiency of zakah distributions based on the Balance Score Card's indicators with the inclusion of governance indicators. Subsequently, the study examines the governance and efficiency of zakah distributions in association with 5 dimensions of dire necessities (daruriyyat) of Maqasid al-Syariah.

\section{Human Dire Necessities}

Dire necessities refer to resources that are required for self-sufficiency. According to Abu Bakar and Abd.Ghani (2011), one's life has no quality if he fails to fulfil his basic needs. Zakah is an instrument ordained in Islamic economic system to assist underprivileged groups in attaining decent, humane and respectable dire necessities through the redistribution of wealth. In this context, everyone is entitled to his dues for his contribution and no one will be deprived of his shares (Ahmed, Khalid, Ammar \& shah, 2017).

In Malaysia, a common measurement of household's basic needs is observed using Poverty Line Income (PLI) set by Economic Planning Unit (EPU) using unidimensional indicator namely monthly income. It is measured based on food and non-food requirements. A household consisting of 4 to 6 people that earns less than RM 930 a month in Malaysian Peninsular or RM 1,170 a month in Sabah/Labuan or RM 990 a month in Sarawak is classified as poor and has a low standard of living (Economic Planning Unit, 2014). The differences in monthly income are due to higher living expenses in the later regions.

Malaysians who earn below PLI are deemed to have yet to fulfil their basic needs or living quality. Nonetheless, the drawback of PLI is its unidimensional feature, where income is the only indicator of basic needs. This is due to the fact that basic needs are not confined to income alone; other elements are equally essential such as dwelling, knowledge, family and food.

Islam outlines in Maqasid al-Syariah that human beings have three levels of needs in the hierarchy, starting from dire necessities (daruriyyat) that is followed by comfort needs (hajiyyat), and finally luxury needs (tahsiniyyat). In contrast to PLI that adopts a unidimensional indicator, Maqasid al-Syariah stipulates that dire necessities (daruriyyat) consist of five dimensions, namely the preservation of faith, physical life, knowledge, family and wealth. Zakaria and Abd Malek (2014) discovered that the efficiency of zakah distribution management is influenced by its ability to fulfil the dire necessities (daruriyyat) of five (5) dimensions as stipulated in Maqasid al-Syariah.

\subsection{Preservation of Faith}

Preservation of faith is the most crucial dire necessity in a Muslim's life. Muslims should align all aspects of their life with the Syariah, including economic, political, religious and social aspects in order to seek the blessings of Allah. All Muslims should be committed to fulfilling their religious duties by performing the five pillars of Islam, namely performing daily prayers five (5) times a day, fasting or abstaining to eat in the month of Ramadhan, distributing zakah and performing hajj in Mecca. Muslims who are incapable to fulfil the preservation of faith are categorised as spiritually poor or unable to meet his self-sufficiency. The studies conducted by Zakaria and Abd. Malek (2014) and Rosbi and Sanep (2009) found that the preservation of faith is positively correlated to the governance and efficiency of zakah distribution. As such, based on prior studies (Zakaria and Abd Malek, 2014; Rosbi and Sanep, 2009), the first hypothesis is proposed below. 
H1: The higher the preservation of faith, the more likely is good governance and efficiency of zakah distribution.

\subsection{Preservation of Physical Self}

Preservation of physical self is the second dire necessity stipulated in Maqasid al-Syariah. This type of preservation covers personal basic needs required in one's daily life such as healthcare, sufficient nutrition, decent shelter, amenities and utilities. One generally strives to fulfil the preservation of his own physical self and that of his dependents. Dependents may consist of offsprings and others who rely their basic needs on an individual. In accordance with this understanding, one should not cause any harm that might jeopardise himself and other parties. Studies have reported that the preservation of physical self can influence zakah efficiency (Zakaria, 2014, Rosbi and Sanep, 2009). Hence, following prior studies (Zakaria, 2014, Rosbi and Sanep, 2009), the second hypothesis is formulated as follows.

$\mathrm{H} 2$ : The higher the preservation of physical self, the more likely is good governance and the efficiency of zakah distribution.

\subsection{Preservation of Knowledge}

The third dire necessity stipulated in Maqasid al-Syariah is the preservation of knowledge or mental development. The mind is a vital component that constitutes a human's life. Therefore, protecting the mind or knowledge means to guard it against any element that can lead a human to destruction (Ibn Ashur, 2006; Likitrattanaporn, 2018). One needs to develop his intellectual levels and skills to support a positive integration within the society. These needs are inclusive of psychological and intellectual factors, for instance, stress management, education achievement and involvement in social activities. Thus, humans need to work hard by acquiring knowledge and utilise their intellectuality for the benefits of themselves, family and society.

Prior studies indicated that zakah efficiency is influenced by the preservation of knowledge (Zakaria, 2014, Rosbi and Sanep, 2009). As such, following prior studies (Zakaria, 2014, Rosbi and Sanep, 2009), the third hypothesis is formulated.

H3: The higher the preservation of knowledge, the more likely is good governance and efficiency of zakah distribution

\subsection{Preservation of Family}

The forth dire necessity is the preservation of family or offspring. One needs a family to enhance the quality of his life and to be able to fulfil the requirement of self-sufficiency. Possessing parenting skills as well as imparting knowledge and skills to children will supplement the preservation of family. In addition, one is responsible to protect the pride and dignity of the family as well as their ancestors. Indeed, these needs are essential in current socio-economic settings where the concept of protecting lineage or dignity encompasses the protection, preservation and support, which begin in the early stage of marriage (Kasule, 2004). For instance, the responsibilities of a husband, wife, parents and children are important in preparing the future generation to face challenges in life (Chapra, 2007).

According to Zakaria (2014) and Rosbi and Sanep, (2009), zakah efficiency is influenced by the preservation of family. Therefore, following prior studies (Zakaria, 2014, Rosbi and Sanep, 2009), the fourth hypothesis is proposed.

H4: The higher the preservation of family, the more likely is good governance and the efficiency of zakah distribution.

\subsection{Preservation of Wealth}

The last dire necessity in Maqasid al-Syariah is the preservation of wealth where one needs fixed assets and durable goods for a decent quality of life. He also must be able to generate income or revenue from economic activities as wealth is the source of financial assets that helps one to spend on food and non-durable goods. In fact, one is allowed to acquire wealth and property as much as possible, but the method of possession should comply with Syariah. Every element in this world, including wealth owned by mankind, is a trust from Allah S.W.T for one to administer, manage and rule. One can only keep it for a brief time before passing it to his descendants (Ahmad and Ibrahim, 2006). In this context, wealth must be cultivated and used wisely and truthfully to fulfil needs and build a comfortable life.

Prior studies indicated that zakah efficiency is influenced by the preservation of wealth (Zakaria, 2014, Rosbi and Sanep, 2009). As such, following the Maqasid al-Syariah and prior studies (Zakaria, 2014, Rosbi and Sanep, 2009), the following hypothesis is proposed. 
H5: The higher the preservation of wealth, the more likely is good governance and efficiency of zakah distribution. The proposed model is depicted in Figure 1.

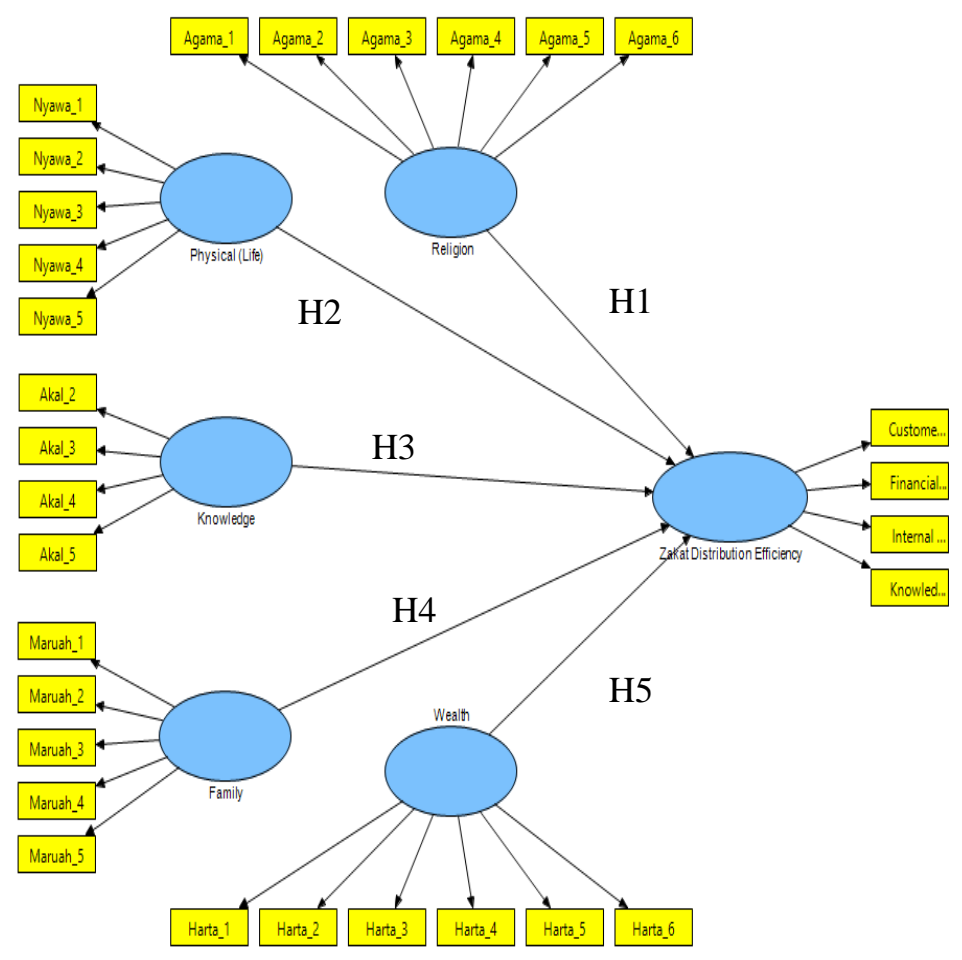

Figure 1. Proposed model

\section{Methodology}

Kelantan State Religious Council or referred as Majlis Agama Islam Kelantan (MAIK) is entrusted to govern and manage the distribution of zakah in the state of Kelantan. As of now, MAIK has initiated 18 zakah distribution programmes including monthly assistance, business assistance, emergency assistance, medical assistance, educational assistance and financial aid to help students further their studies. Respondents in the current paper were selected from Asnaf Business Assistance Programme. This programme embarks with the objectives of assisting zakah beneficiaries' business operations to support them in fulfilling their basic or daruriyyat needs and even transform their life to a better level of comfort or hajiyyat. Meanwhile, the remaining zakah programmes only assist zakah beneficiaries to fulfil their daruriyyat needs on a short period of time. i.e., once the zakah fund is distributed to the beneficiaries, they would immediately dispense the funds for their daily needs.

The sampling frame for Asnaf business assistance programme was based from zakah beneficiaries listing provided by MAIK. There were approximately 600 zakah beneficiaries from 1st September 2017 to 1st February 2018. The researchers distributed 500 sets of a questionnaire to respondents, where 446 were returned, totalling to $89 \%$ response rate. The size of the sample is deemed sufficient as recommended by Roscoe's rule of thumb (1975) in which an appropriate sample size for any research should range from 50 and 500. Meanwhile, Krejcei and Morgan (1970) recommended the sample size of 217 for the population of 550 people. As far as the current study is concerned, the sample size of 446 is sufficient for the population of 600 people.

In collecting the data of the underlying constructs, the study adopted a quantitative survey methodology using a self-administered questionnaire as illustrated in the proposed model. It is important to highlight that all of the items in the measurements were adopted from previously tested scales (Zakaria and Abd Malek, 2014).

The questionnaire constitiuets of three parts; the first part being the respondent's profile. The second part is the question items to measure an endogenous construct i.e., governance and zakah distribution efficiency. Additionally, this construct consists of four dimensions, namely customer satisfaction, internal process, knowledge worker and 
financial performance. Customer satisfaction, internal control, knowledge worker and and financial performance are assessed by $6,5,5$ and 5 items respectively.

The third and last part assesses the five elements of basic needs as stipulated in Maqasid al-Syariah. In this part, there are 7 items that assess preservation of faith, 5 items assessing preservation of physical life, 5 items to assess preservation of knowledge, 5 items that assess preservation of family/offspring and 8 items to assess preservation of wealth. The constructs are assessed using 5-point Likert scales within a continuum that ranges from strongly disagree (1) to strongly agree (5).

To guarantee that the wording used in this questionnaire was clear, comprehensible and the equivalence of the instrument was attained, a pre-test was performed before conducting the final survey. A pre-test is important to unleash any glitches in the instrument and to identify the face validity of the measures.

After the pre-test conditions were fulfilled, there were approximately 500 sets of the questionnaire were distributed to the respondents through the mail. The questionnaire was attached in a stamped envelope with a written address and a cover letter providing a brief explanation on the purpose of the study. Respondents were also assured of the confidentiality and anonymity that the information was intended for research purposes only. They were instructed to reply within 1 week and if there was no feedback after 2 weeks have passed, the researchers would contact the respondents to kindly remind them about the importance of their response on the issues of good governance and efficiency of zakah distribution. Finally, after 1 month, 446 sets managed to be collected, contributing to $89 \%$ rate of response.

This study adopted two statistical techniques in data analysis. First, Statistical Package for Social Sciences (SPSS) version 24 . This technique was used to analyse the preliminary data and provide a descriptive analysis of the sample namely means, standard deviations, frequencies and reliability analysis. Secondly, Structural Equation Modelling (SEM) using Smart PLS (Partial Least Square) M3 version 2.0, adopting the Confirmatory Factor Analysis (CFA). This technique was applied to test both of the measurement and structural models.

Following Anderson and Gerbing (1988), SEM was conducted using a two-stage approach. The first stage involved the assessment of the unidimensionality, followed by the assessment of reliability and validity of the underlying constructs. In investigating the reliability aspect, the internal consistency of measures was assessed using Cronbach's alpha and CFA. Besides, validity criterion, construct (including convergent and discriminant) and external validity were also assessed. After the scale fulfilled all the criteria in the measurement model, the hypotheses would then be tested in the structural model. The relationship between each dimension of five dire necessities of Maqasid al-Syariah was analysed in relation to governance and zakah distribution efficiency using path analysis. The path analysis would examine whether the path is statistically related (Ali \& Haseeb, 2019).

\section{Results and Discussion}

\subsection{Demographic Profile}

The results indicated that 396 or $88.8 \%$ of participants were females while 50 or $11.2 \%$ were males. Approximately, 420 participants or $94.2 \%$ were married while the remaining 26 or $5.8 \%$ were single. The participants' age was divided into 4 categories of which majority of them was between 35 to 44 years ( 374 or $83.9 \%$ ). It was followed by 25 to 34 years and below 25 years with 48 or $10.8 \%$ and 24 or $5.4 \%$ respectively. In terms of education level, the majority or 264 participants (59.2\%) had SPM (SPM is equalled to O Level), trailed by Certificate (109 or $24.4 \%$ ), diploma (48 or $10.8 \%$ ) and SRP/PMR ( 25 or $5.6 \%$ ). The results are indicated in Table 1. 
Table 1. Demographic profile

\begin{tabular}{lll}
\hline Profile & Frequency & Percentage (\%) \\
\hline Sex & & \\
\hline Male & 50 & 11.2 \\
\hline Female & 396 & 88.8 \\
\hline Marital Status & & \\
\hline Single & 420 & 420 \\
\hline Married & 26 & 26 \\
\hline Education & & \\
\hline Below SRP/PMR & 25 & 25 \\
\hline SPM/O-Level & 264 & 264 \\
\hline Certificate & 109 & 109 \\
\hline Diploma & 48 & 48 \\
\hline Age & & 83.9 \\
\hline Less than 25 years & 374 & 10.8 \\
\hline 25 to 34 years & 48 & 5.4 \\
\hline 35 to 44 years & 24 & \\
\hline
\end{tabular}

\subsection{Normality Test}

The normality test was conducted to ensure that the data set is within normal distribution. The results indicated that the mean values are in the range of 4.75 to 5.01. Preservation of faith and physical life constructs score the highest mean of 5.01, while governance and zakah distribution efficiency constructs score the lowest with 4.75 . Kurtosis score was from the lowest of 0.31 to the highest of 0.69 . The range of standard deviation was from 1.15 to 1.31 , which is within the normal distribution of -2 and +2 and hence was accepted for normal univariate distribution (George and Mallery, 2010). Table 2 depicts the constructs, their means and standard deviations.

Table 2. The constructs' means and standard deviation

\begin{tabular}{llc}
\hline Constructs & Mean & Standard Deviation \\
\hline Preservation of faith & 5.01 & 1.26 \\
\hline Preservation of physical-life & 5.01 & 1.25 \\
\hline Preservation of knowledge & 4.90 & 1.31 \\
\hline Preservation of family/offspring & 4.98 & 1.23 \\
\hline Preservation of wealth & 4.98 & 1.15 \\
\hline Governance and zakah distribution efficiency & 4.75 & 1.32 \\
\hline
\end{tabular}

\subsection{Assessment of the Measurement Model}

This study employed Smart PLS ME 2.0 to evaluate the model by assessing the parameters in the outer and inner model (Ringle et al., 2005). This statistical package explains the variance that influences the variance of the endogenous construct (dependent variable). It provides many advantages in relation to distribution requirements, type of constructs, the size of the sample and the complexity of the tested model. The PLS path modelling was applied for this study, with a path weighing scheme for the inside approximation of 200 resampling to obtain standard errors of the estimates. The PLS requires two assessments, namely measurement and structural model (Anderson and Gerbing, 1988).

\subsection{Measurement Model}

In the measurement model, the data were assessed to ensure their reliability and validity. Three assessments were carried out, namely convergent validity, reliability analysis and discriminant validity in order to achieve this purpose, 


\subsubsection{Convergent Validity}

The validity of the constructs was assessed using convergent and discriminant validity. Convergent validity is the degree of multiple items to measure the construct that should theoretically be related, is in fact, related. Following the suggestion by Hair et al. (2010), the convergent validity was tested by three assessments, namely factor loadings, composite reliability (CR) as well as average variance extracted (AVE). Factor loadings of less than 0.6 were deleted as recommended by Chin (1998). Composite reliability shows the degree to which the construct indicators depict the latent construct ranging between 0.815 and 0.861 . These values were more than 0.7 as suggested by Hair et al. (2010). The average variances, representing the overall amount of variance in the measurement accounted for by the latent construct, were between 0.523 and 0.561 . These values also surpassed the recommended value of 0.5 (Hair et al., 2010). In total, 2 items were deleted; knowledge (Akal_1) and internal process item (Proses_4) (see Table 3).

Table 3. Results of measurement model

\begin{tabular}{|c|c|c|c|c|}
\hline Dimensions & Items & Loadings & $\begin{array}{l}\text { Average varian } \\
\text { extracted (AVE) }\end{array}$ & $\begin{array}{l}\text { Composite } \\
\text { reliability }(\mathrm{CR})\end{array}$ \\
\hline \multirow[t]{6}{*}{ Preservation of faith } & Agama_1 & 0.723 & 0.507 & 0.860 \\
\hline & Agama_2 & 0.758 & & \\
\hline & Agama_3 & 0.752 & & \\
\hline & Agama_4 & 0.723 & & \\
\hline & Agama_5 & 0.666 & & \\
\hline & Agama_6 & 0.642 & & \\
\hline \multirow[t]{8}{*}{ Preservation of physical (life) } & Nyawa_1 & 0.693 & 0.546 & 0.857 \\
\hline & Nyawa_2 & 0.783 & & \\
\hline & Nyawa_3 & 0.805 & & \\
\hline & Nyawa_4 & 0.757 & & \\
\hline & Nyawa_5 & 0.646 & & \\
\hline & Famili_3 & 0.758 & & \\
\hline & Famili_4 & 0.779 & & \\
\hline & Famili_5 & 0.697 & & \\
\hline \multirow[t]{11}{*}{ Preservation of wealth } & Harta_1 & 0.692 & 0.523 & 0.868 \\
\hline & Harta_2 & 0.746 & & \\
\hline & Harta_3 & 0.713 & & \\
\hline & Harta_4 & 0.760 & & \\
\hline & Harta_5 & 0.751 & & \\
\hline & Harta_6 & 0.673 & & \\
\hline & Kepuasan_1 & 0.676 & 0.544 & 0.856 \\
\hline & Kepuasan_2 & 0.747 & & \\
\hline & Kepuasan_3 & 0.805 & & \\
\hline & Kepuasan_4 & 0.780 & $\mathrm{~dB}$ & \\
\hline & Kepuasan_5 & 0.667 & us & \\
\hline
\end{tabular}

\subsubsection{Discriminant Validity}

Discriminant validity is conducted to examine whether items which are not supposed to be related are differentiated among constructs (Cheung and Lee, 2010). According to Fornell and Larcker (1981), the discriminant validity is 
ascertained by calculating the correlations between constructs and the square root of the average variance extracted for that construct. The results indicated that all square roots of the average variance were higher than the correlation values in the row and the column, indicating adequate discriminant validity (refer to Table 4). All of the correlation values that are less than 0.85 of which discriminant validity is likely to exist between the constructs. In summary, the measurement model demonstrated adequate convergent validity and discriminant validity.

Table 4. Results of discriminant validity

\begin{tabular}{llllll}
\hline Construct & $\begin{array}{l}\text { Preservation } \\
\text { of family }\end{array}$ & $\begin{array}{l}\text { Preservation } \\
\text { of family }\end{array}$ & $\begin{array}{l}\text { Preservation } \\
\text { of family }\end{array}$ & $\begin{array}{l}\text { Preservation } \\
\text { of family }\end{array}$ & $\begin{array}{l}\text { Preservation } \\
\text { of family }\end{array}$ \\
\hline Preservation of family & 0.732 & & & & \\
\hline Preservation of knowledge & 0.473 & 0.725 & & & \\
\hline Preservation of physical (life) & 0.524 & 0.447 & 0.739 & & \\
\hline Preservation of faith & 0.555 & 0.502 & 0.567 & 0.712 & \\
\hline Preservation of wealth & 0.473 & 0.405 & 0.511 & 0.535 & 0.723 \\
\hline
\end{tabular}

Note: Diagonals are the square root of AVE while the off-diagonals are the correlations.

\subsection{Reliability Analysis}

Reliability analysis refers to the fact that a measuring instrument should consistently represent the construct that it is measuring (Sekaran and Bougie, 2010). Table 5 illustrates that all alpha values of the variables are between 0.827 and 0.918 which are greater than 0.7 as recommended by Sekaran (2010) (refer to Table 5). These values indicate that the data are reliable for further analysis (Nunally, 1978).

Table 5. Results of reliability test

\begin{tabular}{lccc}
\hline Constructs & Cronbach's $\alpha$ & Loading range & Number of items \\
\hline Preservation of faith & 0.805 & $0.642-0.758$ & 5 \\
\hline Preservation of physical life & 0.789 & $0.646-0.693$ & 5 \\
\hline Preservation of knowledge & 0.794 & $0.661-0.811$ & 4 \\
\hline Preservation of family & 0.782 & $0.686-0.779$ & 5 \\
\hline Preservation of wealth & 0.817 & $0.693-0.760$ & 6 \\
\hline Customer satisfaction & 0.787 & $0.667-0.805$ & 5 \\
\hline Internal process & 0.734 & $0.637-0.829$ & 4 \\
\hline Knowledge worker & 0.797 & $0.652-0.801$ & 5 \\
\hline Financial management & 0.812 & $0.717-0.831$ & 3 \\
\hline
\end{tabular}

\subsection{The Structural Model}

The structural model reflects the causal relationships between constructs in the model (path coefficients and the $R^{2}$ value) (Sang and Bogie, 2010). Both $R^{2}$ and path coefficients (beta and significant value) indicate the strength of data in supporting the hypothesised model (Chin, 1998, Sang et al., 2010). Table 6 and Figure 2 indicate the structural model's results from the PLS output. $R^{2}$ indicates that $59.6 \%$ of governance and zakah distribution efficiency is explained by the variance in the preservation of faith, preservation of physical self, preservation of knowledge, preservation of family/offspring and preservation of wealth. The higher the preservation of faith $\left(\beta_{1}=0.265, p<0.01\right)$ physical self $\left(\beta_{2}=0.117, p<0.01\right)$, knowledge $\left(\beta_{3}=0.145, p<0.01\right)$, family/offspring $\left(\beta_{4}=0.212, p<0.01\right)$, and wealth $\left(\beta_{5}=0.254, p<0.01\right)$, the more likely is governance and zakah distribution efficiency. All hypotheses (H1, $\mathrm{H} 2, \mathrm{H} 3, \mathrm{H} 4$ and H5) are in fact, supported. The structural model is illustrated in Figure 2. 


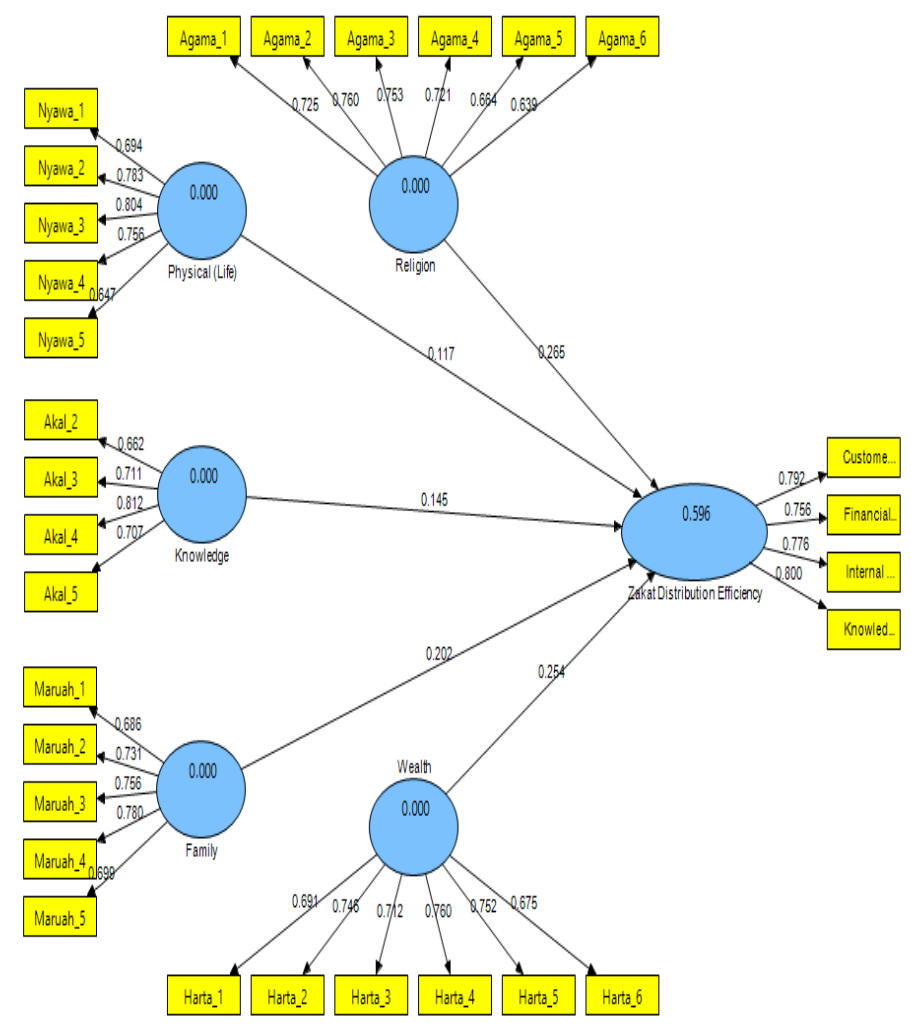

Figure 2. The structural model

\section{Discussion}

The preservation of faith is hypothesised to positively influence governance and zakah distribution efficiency. The results support the hypothesis $\left(\beta_{1}=0.212, p<0.01\right)$ and concur with the work of previous studies (Zakaria and Abd Malek, 2014; Rosbi and Sanep, 2009). Hence, it is concluded that the higher the preservation of religious, the more likely is good governance and zakah distribution efficiency can be exercised.

Does preservation of physical self influence governance and zakah distribution efficiency? The results support the hypothesis $\left(\beta_{2}=0.145, p<0.01\right)$ and are in tandem with previous studies (Zakaria and Abd Malek, 2014; Rosbi and Sanep, 2009). Therefore, it is concluded that the higher the preservation of physical self, the more likely is good governance and zakah distribution efficiency.

Does the preservation of knowledge influence governance and zakah distribution efficiency? The results reveal that the hypothesis is supported $\left(\beta_{3}=0.145, p<0.01\right)$ that is also in line with a previous study (Zakaria and Abd Malek, 2014). As such, it is concluded that the higher the preservation of knowledge, the more likely is good governance and zakah distribution efficiency.

Does preservation of family/offspring influence governance and zakah distribution efficiency? The results reveal that the hypothesis is supported $\left(\beta_{4}=0.145, p<0.01\right)$ and concur with prior studies (Zakaria and Abd Malek, 2014; Rosbi and Sanep, 2009). Therefore, it is concluded that the higher the preservation of physical self, the more likely is good governance and zakah distribution efficiency.

Does the preservation of wealth influence governance and zakah distribution efficiency? The results concur with the hypothesis $\left(\beta_{5}=0.145, p<0.01\right)$ and correlate with a previous study (Zakaria and Abd Malek, 2014). Finally, it is concluded that the higher the preservation of physical self, the more likely is good governance and zakah distribution efficiency.

\subsection{The Implication to the Maqasid Al-Syariah}

The results provide an implication that dire necessities are not only confined to monetary items; other non-monetary items as stipulated in Maqasid al-Syariah should also be emphasised. Consequently, a holistic and fair measurement of the basic needs can be understood and provided sufficiently. 


\subsection{The Implication to Zakah Institutions}

The results provide fruitful insights to zakah institutions regarding the importance of good governance and zakah distribution efficiency in fulfilling the objective of Maqasid al-Syariah as well as for the betterment of Muslim society. In this context, the institutions should formulate short- and long-term strategic plans to ensure the fulfilment of all five dire necessities in supporting the transformation of beneficiaries' life from daruriyyat to comfort living (hajiyat).

To fulfil the first basic need, namely preservation of faith, it is suggested that zakah institutions establish various programmes in relation to religious and spiritual activities. These programmes would help to overcome the feeling of inadequacy and inferiority that commonly affect the poor due to their living condition. As spiritual adequacy is related to tauhid (belief), these programmes would consequently enhance their spiritual belief that will strengthen their faith in Islam. Having strong Islamic conviction will lead them to further upgrade their life spiritually, emotionally, physically, and economically. As a trusted agent, zakah institution plays a proactive role in helping the beneficiaries to fulfil these needs.

To fulfil the second basic need that is the preservation of physical self, zakah institutions are recommended to conduct programmes dedicated to resolve poverty issues and transform the lives of the beneficiaries from poverty-stricken (daruriyyat needs) (fulfilling their basic needs) to a level of comfort living (hajiyat). Accordingly, zakah institutions should use its discretion in identifying effective instruments to channel the fund. A decent living standard must cater to two components, namely essential (daruriyyat) and comfort (hajiyyat). The proportion of zakah received by the poor should help them improve their living standard, namely daruriyyat and hajyiyat needs which constitute the minimum living standard and this is aligned with the nation's aspiration to become a zero-poverty nation.

With regards to the third need which is the preservation of knowledge, zakah institution is suggested to initiate educational and motivational programmes that can motivate and educate beneficiaries to be independent and self-sustained. This can be achieved if zakah is distributed in the form of capital, to support the unemployed, single mother, physically disabled people, underprivileged groups and others. In other words, zakah can act as important social insurance for every member of the Muslim community where a bright future is guaranteed.

For the forth need, namely preservation of family or offspring, zakah institution is recommended to instil good values based on love, mutual solidarity and brotherhood in order to purge from the poor, feelings of hatred and animosity that beneficiaries might have for the rich. Apart from providing protection and assistance to help them tackling financial and emotional difficulties, the institution could also initiate educational activities that enhance the unity among beneficiaries and their families.

For the fifth need which is the preservation of wealth, zakah institution must ensure that zakah fund would assist beneficiaries in attaining a level of self-sufficiency and comfort living through the possession of wealth. According to Mohamed et al., (2018), the best living quality is closely related to moderation. The noble al-Quran has clearly highlighted general principles in making use of wealth in a Muslim's life where Muslims are advised to utilise their wealth appropriately. It is important to highlight that one needs wealth to help oneself fulfil the physiological needs.

\section{Conclusion}

In summary, the findings of this indicated that beneficiaries perceived good governance and efficiency of zakah distributions would be determined through the fulfilment of all five elements of dire necessities within Maqasid al-Syariah. The most significant dimension is the preservation of faith, followed by preservation of wealth, preservation of family, preservation of knowledge and finally preservation of physical self. This discovery provides useful insights to zakah institutions to comprehensively initiate both short and long-term plans, tailored to each dire necessities to ensure the employment of appropriate assistance for beneficiaries. As social religious agents, zakah institutions are responsible to carry out their duties as outlined by Syariah to benefit the zakah beneficiaries, zakah payers and the religion at large. Finally, the Maqasid al-Syariah in zakah jurisprudence will be fulfilled if zakah institutions are able to assist beneficiaries in fulfilling the five elements of basic needs and eventually transform beneficiaries' lives from being on the level of dire necessities (daruriyyat needs) to the level of comfort living (hajiyyat).

\section{References}

Abd Wahab, N., \& Abdul Rahman, A. R. (2011). A Framework to analyse the efficiency and governance of zakat institutions. Journal of Islamic Accounting and Business Research, 2(1), 43-62. https://doi.org/10.1108/17590811111129508 
Abdul Rasool, M. S., Mohd Salleh, A., \& Mohd Harun, M. F. (2010, December21-22). Poverty measurement in Malaysia zakat institutions: Non-monetary indicators. Zakat Transformation: From Subsistence to Productive. Proceedings of the $4^{\text {th }}$ ISDEV International Islamic Development Management Conference (IDMAC 2010). Universiti Sains Malaysia.

Abu Bakar, M., \& Abd Ghani, A. (2011). Towards achieving the quality of life on the management of zakat distribution to the rightful recipients (the poor and needy). International Journal of Business and Social Sciences, 2(4), 237-245.

Ahmed, U., Khalid, N., Ammar, A., \& Shah, M. H. (2017). Assessing moderation of employee engagement on the relationship between work discretion, job clarity and business performance in the banking sector of Pakistan. Asian Economic and Financial Review, 7(12), 1197-121. https://doi.org/10.18488/journal.aefr.2017.712.1197.1210

Al Zuhaili, W. (2005). Usul al Fiqh al Islami, Dar al Fikr Damsyiq.

Ali, A., \& Haseeb, M. (2019). Radio frequency identification (RFID) technology as a strategic tool towards higher performance of supply chain operations in textile and apparel industry of Malaysia. Uncertain Supply Chain Management, 7(2), 215-226. https://doi.org/10.5267/j.uscm.2018.10.004

Atkinson, R. (2000). Combating social exclusion in Europe: The New Urban Policy Challnge. Urban Studies, 37, 67-79. https://doi.org/10.1080/00420980050011226

Auda, J. (2008). Maqasid al-Syariah and Introductory Guide. Institute of Islamic Thought.

Auda, J. (2008). Maqasid al-Syariah as philosophy of Islamic law: A system approach. Malaysia: The International Institute of Advanced Islamic Studies (IASC).

Cheung, M. K., \& Lee, K. O. (2010). A theoretical model of intentional social networks. Decision Support Systems, 49(1), 24-30. https://doi.org/10.1016/j.dss.2009.12.006

Chin, W. (1998). Issues and opinions on structural equation modelling. MIS Quarterly, 22(1), 7-16.

Cohen, S., Thuiraasi D., \& Kandilarou, M. (2008). Performance parameters interrelations from a balanced scorecard perspective. An analysis of Greek companies. Managerial Auditing Journal, 23(5), 485-503. https://doi.org/10.1108/02686900810875307

Department of Statistics Malaysia. (2016). Population distribution and basic demographic characteristics. Retrieved $30 \quad$ September 2018, from http://www.statistic.gov.my/poral/download_population/fi;es/cencus2010/Taburan_penduduk_dan_ciri-ciri_asa s_demographi.pdf

Economic Planning Unit. (2016). The highest hardcore poor. Retrieved 30 September 2018, from http://www.epu.gov.my

Farrell, M. J. (1957). The measurement of productive efficiency. Journal of the Royal Statistical Society, 120, 253-281. https://doi.org/10.2307/2343100

Hair, J. F., Black, W. C., \& Babin, R. E. (2010). Multivariate Data Analysis. New Jersey: Upper saddle River, Prentice-Hall.

Khan, N., Ali, K., Kiran, A., Mubeen, R., Khan, Z., \& Ali, N. (2016). Factors that affect the derivatives usage of non-financial listed firms of Pakistan to hedge foreign exchange exposure. Journal of Banking and Financial Dynamics, 1(1), 9-20. https://doi.org/10.20448/journal.525/2017.1.1/525.1.9.20

Khan, S. N., \& Ali, E. I. E. (2017). The moderating role of intellectual capital between enterprise risk management and firm performance: A conceptual review. American Journal of Social Sciences and Humanities, 2(1), 9-15. https://doi.org/10.20448/801.21.9.15

Khan, Y., Hassan, T., Yi, W. M., \& Gulzar, R. (2018). A Comparative Analysis Based on Economic Factors of Students Emigration from South Asia. Asian Journal of Economics and Empirical Research, 5(2), 201-208.

Kojo, R., \& Paschal, N. (2018). Urban Population Growth and Environmental Sustainability in Nigeria. Journal of Empirical Studies, 5(1), 12-19. https://doi.org/10.18488/journal.66.2018.51.12.19

Krejcie, R. V., \& Morgan, D. W. (1970). Determining sample size for research activities. Educational and Psychological Measurement, 30, 607-610. https://doi.org/10.1177/001316447003000308 
Lan, Y. W., Lin, D., \& Lin, L. (2017). Why are the Performances of Business Groups Different? A Case Study of Formosa Plastics Group and Far Eastern Group. Asian Journal of Economics and Empirical Research, 4(2), 106-120. https://doi.org/10.20448/journal.501.2017.42.106.120

Lari, L. R. A., NYangweso, P. M., \& Rono, L. J. (2017). Determinants of Technical Inefficiency of Saccos in Kenya: A Net Operating Cash Flows Output Slack Analysis. Asian Journal of Economics and Empirical Research, 4(2), 49-60. https://doi.org/10.20448/journal.501.2017.42.49.60

Lee, U. H. M. S., Ismail, A., \& Sanusi, N. S. A. (2018). Ethical Climate as a Determinant of Organizational Commitment. International Journal of Asian Social Science, 8(8), 534-539. https://doi.org/10.18488/journal.1.2018.88.534.539

Likitrattanaporn, W. (2018). A Study of Language Learning Strategies for Practical Use through the Process of Cooperative Learning. International Journal of Educational Technology and Learning, 3(1), 35-44. https://doi.org/10.20448/2003.31.35.44

Mohamed, N., Mustaki, M., Syed Yusuf, S. N., \& Zakaria, M. (2018). Management control system in Asnaf Entrepreneurship Development Program by Lembaga Zakat Selangor, Jurnal Pengurusan, 53, 1-16.

Nunally, J. C. (1978). Psychometrica Theory (2nd ed). New York: McGraw-Hill.

Ringle, C., Wende, S., \& Will, A. (2005). Smart PLS 2.0 (Beta) Hamburg. Retrieved from www.smartpls.de

Rosbi, A. R., Sanep, A., \& Hailani, M. T. (2009). Keberkesanan agihan zakat mengikut perspektif Maqasid al-Syariah. Seminar Antara bangsa Muamalat Kewangan Ekonomi Islam. Universiti Kebangsaan Malaysia.

Roscoe, J. T. (1975). Fundamental Research Statistics for the Behavioural Sciences (2nd ed.). New York: John Wiley \& Sons Inc.

Sang, S., Lee, J. D., \& Lee, J. (2010). E-government adoption in Cambodia: A partial least square approach. $\begin{array}{lllll}\text { Transforming Government, People, Process and Policy, } 4, & \text { 138-157. }\end{array}$ https://doi.org/10.1108/17506161011047370

Sekaran, U., \& Bougie, R. (2010). Research methods for business: A skill building approach. London: Wiley.

Zakaria, M. (2014). The influence of human needs in the perspective of Maqasid al-Syariah on Zakat Distribution Effectiveness. Asian Social Science, 10(3), 165-173. https://doi.org/10.5539/ass.v10n3p165

Zakaria, M. (2018). Role of zakah institution in governing and transforming beneficiary's living standard from the level of daruriyyat (dire necessities) to hayiyyat (comfort living) in Kelantan. Pertanika Journal of Scholarly Research Review, 4(2), 43-48.

Zakaria, M., \& Abd Malek, N. (2014). Effects of human needs based on the integration of needs as stipulated in Maqasid Syariah and Maslow's hierarchy of needs on zakah distribution. JurnalPengurusan, 40, 41-52. https://doi.org/10.17576/pengurusan-2014-40-04 